as on finance; but it is clear that the belief that the biological sciences in the tropics can progress in the absence of strong support to taxonomy is quite unrealistic.

The preparatory meeting accepted gratefully an invitation from the delegate for France that the new Humid Tropics Advisory Committee, which Unesco has been asked to set up, should hold its first meeting, if possible in 1957, at Abidjan in the Ivory Coast. At the symposium on tropical vegetation it was recommended that this meeting should be preceded by another symposium with the theme "Ecological Studies of 'Tropical Vegetation in Relation to Soils"

P. W. RiCHARDS

\title{
GEOCHEMICAL AND GEOPHYSICAL LABORATORIES IN THE IMPERIAL COLLEGE
}

\section{By Prof. DAVID WILLIAMS}

$\mathrm{O}$ NE of the initial steps towards the goal of full expansion of the Imperial College of Science and Technology, London, has been the addition of a top story to the Royal School of Mines. This story, incorporated in the Department of Geology, provides about 11,000 sq. $\mathrm{ft}$. of accommodation for the Sub. departments of Geochemistry and Applied Geophysics, which are mainly concerned with training and research in certain modern aspects of mineral exploration. The new laboratories were open to inspection on May 24.

The Geochemistry Section comprises a main laboratory for the chemical analysis of minerals, rocks and soils, two laboratories devoted to spectrochemical analysis and the study of trace elements in geological material by means of large quartz spectrographs and other modern instruments, together with sample preparation and balance rooms. X-ray equipment for mineral identification is available, and a mass spectrometer is shortly to be installed. Several research cubicles are provided for postgraduates engaged in the investigation of a wide range of pioblems in pure geochemistry and geochemical prospecting.

Analysis of silicate rocks by the so-called classical methods is a protracted and highly skilled technique. Fortunately, however, rapid spectrochemical methods of silicate analysis, recently devised in the United States and substantially modified as the result of research in the new Pure Geochemistry Laboratories of the College, now permit a productivity of ten complete and reliable analyses per man-week. Thanks to this increased tempo the Department has been able to make comprehensive studies of the chemical changes induced in sediments by the emplacement of granites in Donegal, and to investigate chemical variations in the serpentinized basic igneous rocks of Insch in the Scottish Highlands. The research programme in pure geochemistry also includes a comparison of different analytical procedures, using spectrographic, polarographic, chromatographic and colorimetric techniques. This study should indicate the most appropriate method to adopt for determining particular elements, and it is hoped eventually to offer interested workers in other universities and research establishments a variety of silicate rock powders of guaranteed major- and minor-element composition.

Although much is known about the partitioning of certain elements among different minerals and among varieties of particular species, little research has yet been concentrated on the geochemistry of the less common metals, including those of the rare-earth group. Timely investigations, however, are now under way in the new Department concerning the distribution in minerals of cerium, gadolinium, terbium and other rare-earth elements, knowledge of which will be especially valuable in view of the increasing interest in atomic energy. Regional studies of the distribution of trace elements in specific ore minerals continue to receive attention, and the dispersal of certain elements throughout soil profiles in temperate regions is under consideration. A virgin field of attractive research in nuclear geology awaits the arrival in the Department of a mass spectrometer capable of determining the isotopic abundance of a wider range of elements than has hitherto been investigated anywhere. Among the many problems to be studied is the isotopic constitution of copper, zine and other metals within a single sulphide deposit and within a particular mineralized district, an inquiry which should not only shed light on the origin of the deposits but may also herald a novel approach to mineral exploration.

In applied geochemistry, a flourishing research school is primarily concerned with critical studies of existing methods of geochemical prospecting, with the development of new field and laboratory techniques, and with the fundamental principles involved in the formation and detection of geochemical anomalies of economic significance. Geochemical methods of prospecting rely on the presence of significant traces of metals naturally dispersed in the rocks and soils near an ore-body, in the vegetation growing on these soils, or in the waters and sediments of streams draining the mineralized area. Thus, although there may be no visible manifestations of mineralization, the presence of concealed mineral deposits may be revealed by the detection of anomalous concentrations of metals in surface materials. Since the concentrations involved are usually very minute, rapid and simple trace analytical techniques have been specially devised to detect them. A Geochemical Prospecting Research Centre has been established in the Department, partly with the aid of funds from the Colonial Office and the Department of Scientific and Industrial Research, and active research is being carried out in various parts of Africa and Britain in mineralized areas containing cobalt, copper, gold, lead, zinc and other metals. Results to date augur well for the continued success of this new method of discovering minerals.

The Applied Geophysics Department is provided with a diversity of modern prospecting instruments, including vertical and horizontal magnetometers, a Worden and a North American gravity meter, seismic equipment and a variety of electrical instruments for spontaneous polarization, resistivity and elector- 
magnetic surveys. Facilities are available for testing and calibrating these instruments and also for measuring some of the relevant physical properties of rocks and minerals. In the students' laboratory model experiments, simulating field conditions, have been developed to illustrate many of the principles employed in geophysical prospecting. A main laboratory and a number of small ones are devoted to research, and a workshop affords facilities for the construction and development of special equipment.

Current research in geophysics includes gravitymeter surveys along the margin of a gabbro mass near Insch in Scotland, and the development of an automatic method of computing the gravitational effects of various types of geological bodies. Studies of Tertiary igneous rocks in Mull and North Wales have indicated that during their extrusion or intrusion many of these rocks were magnetized in a direction opposite to that of the Earth's present field. While any theory of the Earth's magnetism must account for this adverse magnetism, possibly by invoking a reversal of the Earth's field in the geological past, the results obtained in these academic studies have an obvious bearing on the geological interpretation of magnetic surveys for mineral deposits. An attempt is now being made to use the techniques of palæomagnetism for studying the physical conditions which operated during the emplacement of granites and the injection of dykes.

On the instrumental side a flux-gate mag netometer (of the type used in aeromagnetic surveying) is being modified for use at sea, to be towed behind a ship; with this instrument it is hoped soon to make magnetic measurements in the North Atlantic. Development of a novel type of magnetometer based on nuclear magnetic resonance is expected to result in the speeding up of magnetic surveys on land, the instrument consisting essentially of a bottle of water, an electromagnet and a detector coil to measure the frequency of proton precession.

Seismic research is directed towards the production of simpler and more reproducible shocks, using an electromechanical device. Investigations, particularly of frequency attenuation and phase changes, are being continued and the new technique should prove valuable in helping to decipher shallow geological structures. Promising results have attended the evolution of an induced polarization method of locat. ing good conducting ore-bodies enveloped by an electrolyte, and equipment is now being constructed for field-trials over known metalliferous deposits.

\section{OBITUARIES}

Prof. S. R. K. Glanville, F.B.A.

Stephen Ranulph Kingdon Glanville, Provost of King's College, Cambridge, and Herbert Thompson professor of Egyptology in the University, died, very suddenly, on the morning of April 26, his fifty-sixth birthday. The news of his death came as a great shock, not only to his professional colleagues, but also to men and women in many countries; for there were few who knew him who did not come to rely on him for friendship and sympathy.

Glanville was the eldest son of Stephen James Glanville and was born in Westminster in 1900. He was educated at Marlborough and at Lincoln College, Oxford, where he was a modern history scholar. $\mathrm{He}$ graduated in Literæe Humaniores in 1922. Chance largely led him to accept a post as an English teacher in the Egyptian Delta town of Mansūrah. Once there, he fell in love with the country and its people, and set himself to study them. He joined the Egypt Exploration Society's excavations at Tell-el-Amarneh in the season of 1923, the beginning of his long record of devoted service to the Society as a field-worker, and as member and chairman of committee. In 1924, he was appointed an assistant keeper in the Department of Egyptian and Assyrian Antiquities in the British Museum, where he remained until 1933. $\mathrm{He}$ returned, however, to Egypt to work at his beloved Tell-el-Amarneh in 1925, and at Armant in 1928, and contributed to the publications on both sites. He held the Laycock Studentship of Egyptology at Worcester College, Oxford, during 1929-35.

At the British Museum, the major outstanding task of the Department was the publication of its demotic papyri. Demotic is a cursive script in which the Egyptians wrote their documents from the seventh century B.C. until the fourth century A.D.; and in 1924 there were comparatively few aids for its study. Inspired by Sir Herbert Thompson, who became his teacher, benefactor and friend, Glanville undertook this task and did pioneer work. His "Catalogue of the Demotic Papyri in the British Museum, Vol. 1: A Theban Archive of the Reign of Ptolemy I Soter" (1939), and Thompson's "A Family Archive from Siut" (1934), set a new standard and method for the publication of demotic contracts. By painstaking compilation of family genealogies and topographical plans of streets and houses, they made the dry legal formulæ yield up a brilliant and intimate picture of the social and family life of Egyptian provincial towns in the Ptolemaic period. Vol. 2 of Glanville's "Catalogue", "The Instructions of "Onkhsheshonqy" (1956), of which he received the first copy a few weeks before his death, broke fresh ground; in it he deciphered and translated what may well be the last great "Wisdom" book from Egypt. His deep understanding, both of Egypt and of human nature, enabled him often to interpret what might have remained dark to a more cloistered mind; while his firm critical judgment and keen historical sense controlled his imagination and ensured his accuracy.

But Glanville was by no means a one-sided scholar. During his time at the Museum, apart from editing the valuable "Studies presented to F. Ll. Griffith" (1932), he published many articles on the earlier literature and history of Egypt, and acquired a deep knowledge of Egyptian objects, for which he had always had a rare feeling. 'This became of the utmost importance at University College, London, where he was appointed a reader in 1933, and in 1935 Edwards professor of Egyptology; for his chief task there was the cataloguing of the Petrie Collection. Unfortunately, his work for it was undone by the Second World War. Meanwhile, he edited the "Legacy of Egypt" (Clarendon Press, 1942). During the War he served in the Royal Air Force, in which he reached the rank of wing commander, and was made M.B.E. and received Czechoslovak, 